A RCHIWA, BIBLIOTEKI

I MUZEA KOŚCIELNE 112 (2019)

https://doi.org.10.31743/abmk.2019.112.16

\title{
ŹRÓDLA REKOPIŚMIENNE KLASZTORU KLARYSEK GNIEŹNIEŃSKICH W ARCHIWUM ARCHIDIECEZJALNYM W GNIEŹNIE. STAN WIEDZY, PREZENTACJA SPUŚCIZNY I MOŻLIWOŚCI BADAWCZE
}

\section{Streszczenie}

Celem artykułu jest prezentacja i wstępna analiza spuścizny rękopiśmiennej klasztoru klarysek w Gnieźnie, która po kasacie klasztoru trafiła w XIX stuleciu, zapewne drugiej jego połowie, do Archiwum Kapituły Metropolitalnej, obecnie zaś znajduje się w zasobie Archiwum Archidiecezjalnego w Gnieźnie. Do tej pory cieszyła się ona niewielkim zainteresowaniem badaczy. Na zbiór składają się rękopisy, dokumenty i dyplomy pergaminowe, z których większość znajduje się w zbiorze akt luźnych - A. Cap. Luzy Klaryski Gniezno to ponad 2500 jednostek i ponad 4000 kart.

27 rękopisów przechowywanych jest w kilku zespołach: sześć jednostek w zespole Zakon Klarysek w Gnieźnie (ZKG), 21 zaś w dziale Archiwum Kapituły Metropolitalnej - A. Cap. B - te ostatnie dotyczą spraw gospodarczo-rachunkowych.

W grupie rękopisów można wyróżnić trzy kategorie: prawno-normatywne, czyli reguły i konstytucje (dwa egzemplarze), księgi liturgiczne (pięć) oraz ceremoniał obłóczyn, a także rachunkowo-gospodarcze. Ta ostatnia grupa jest najliczniejsza. Obejmuje dziesięć rękopisów expensów illub perceptów konwentu począwszy od najstarszego z 1613 r., ponadto inwentarz majątku wiejskiego klarysek z 1593 r. i dziewięć jednostek z drugiej połowy XVIII w. zawierających rozliczenia z poddanymi w mieście klasztornym Kostrzynie oraz wsiach należących do wspólnoty. Bezcennym kodeksem, wpisującym się w twórczość piśmienniczą klasztorów epoki nowożytnej jest egzemplarz zatytułowany: „Księgi wszystkich spraw konwentu gnieźnieńskiego zakonu S. Klary. To jest katalog wszystkich sióstr zakonnych w tym klasztorze od pamięci ludzkiej professowanych żywych i zmarłych. Przytem inwentarz

* Olga Miriam Przybyłowicz - dr historii; adiunkt w Instytucie Archeologii i Etnologii PAN; e-mail: olgamiriam@interia.pl

https://orcid.org/ 0000-0003-3422-550X 
wszystkich dóbr prowentów także i przywilejów tegoż klasztoru [...] pilnie pisane w roku pańskim 1609”. Ma 802 papierowe strony na których znajduje się dukt kilkudziesięciu rąk. Jego tematyka to zarówno bogate wiadomości prozopograficzne, jak i gospodarcze (ponad połowa wpisów), a także informacje o realiach życia i funkcjonowaniu klauzurowej wspólnoty.

Szeroki wachlarz informacji zamieszczonych w rękopisach pozwala na stwierdzeni iż mimo stosunkowo niewielkiego zbioru jest to spuścizna niezwykle cenna. Jeszcze większy ładunek informacji przynoszą akta luźne. Szczegółowe, żmudne badania, szczególnie rękopisów rachunkowo-gospodarczych, zawierających informacje o świecie rzeczy i ludzi, pozwolą w przyszłości na poznanie kwestii zarządzania majątkiem, kondycji finansowej wspólnoty w XVI-XVIII stuleciu, w końcu sposobu funkcjonowania klasztoru w gospodarce miejskiej i społeczeństwie Gniezna epoki nowożytnej. Dopiero drobiazgowa analiza sprawi, że będzie można udzielić odpowiedzi na wiele pytań dotyczących spraw wewnętrznych konwentu, kultury materialnej i życia codziennego zakonnic, a przede wszystkim gospodarki klasztornej: dochodowości dóbr, bilansowania budżetu, struktury perceptów i expensów, poziomu życia zakonnic.

Słowa kluczowe: monastycyzm; klaryski; Gniezno; archiwalia; rękopisy

Klasztor klarysek w Gnieźnie, który miał zostać ufundowany według tradycji franciszkańskiej przez księcia wielkopolskiego Bolesława Pobożnego i jego żonę Jolentę ${ }^{1}$, lecz zachowane źródła i losy jej po śmierci małżonka w 1279 r. wskazują na późniejsze sprowadzenie zakonnic, ma dość ciekawą i różnorodną zachowaną spuściznę archiwalną, która została do tej pory wyzyskana przez badaczy w niewielkim stopniu ${ }^{2}$. Najważniejszym w odtworzeniu najwcześniejszych dziejów jest dokument Przemysła II z 1284 r., w którym książę wielkopolski powołał się na pamięć stryja Bolesława i prośby Jolenty, czyniąc nadania dla klasztoru klarysek $^{3}$. Ten akt uznać można za właściwą fundację wiążącą się z inicjatywą

${ }^{1} \mathrm{O}$ dacie $1267 \mathrm{w}$ wizytacji ministra Modesta Wybranowskiego z 1637 r., Archiwum Franciszkanów w Krakowie (dalej: AFKrak.), A. Karwacki, Materiały do historii konwentów franciszkańskich Prowincji Polskiej, t. 9, Essen-Gdańsk 1999, s. 178. O Bolesławie jako fundatorze w Kronice wielkopolskiej, lecz w miejscu odległym chronologicznie - dopiero przy okazji wstąpienia do klasztoru pierworodnej córki pary - Anny urodzonej w roku 1276, Kronika wielkopolska, w: Monumenta Poloniae Historica (dalej: MPH) s.n, t. 8, wyd. B. Kürbis, Warszawa 1970, s. 262. O Bolesławie także, Memoriale ordinis fratrum a fr. Ioanne de Komorowo compilatum, w: MPH, t. 5, wyd. X. Liske, A. Lorkiewicz, s. 95.

${ }^{2}$ W tym samym roku zmarł mąż jej siostry Kingi - Bolesław Wstydliwy. Księżna Jolenta udała się do Krakowa, a następnie Starego Sącza do Kingi fundującej wówczas klasztor klarysek. To właśnie w Starym Sączu Jolenta mogła nie tylko pogłębić pobożność wyniesioną z dworów węgierskiego i krakowskiego, na którym się wychowywała, ale podjąć postanowienie o przyjęciu habitu i fundacji w Gnieźnie. Złożyła śluby zakonne przed 1285 r., o czym świadczy dokument księcia pomorskiego Mściwoja II, Kodeks dyplomatyczny Wielkopolski (dalej: KDW), wyd. I. Zakrzewski, t. 1, Poznań 1877, nr 556; O.M. Przybyłowicz, Reguła zakonna jest wozem do nieba. Realia życia w klasztorach klarysek w Małopolsce, Wielkopolsce i na Ślasku, Warszawa 2016, s. 34 i n.

${ }^{3}$ Dokument fundacyjny nie zachował się. Nadanie Przemysła II, KDW nr 550. K. Jasiński, Przemyst, w: Polski Stownik Biograficzny (dalej: PSB), t. 28, s. 730-733; K. Ożóg, Przemyst, w: 
księżnej, zapewne nie dysponującej odpowiednimi środkami finansowymi oraz działaniami Przemysła II, który stał się gwarantem zapewnienia bytu klauzurowej wspólnocie ${ }^{4}$.

Niniejszy artykuł prezentuje źródła oświetlające dzieje wspólnoty Ubogich Panien w Gnieźnie od XIII po XIX stulecie zachowane w Archiwum Archidiecezjalnym w Gnieźnie (dalej: AAG). Spuścizna rękopiśmienna nie jest tak skromna, jak wynikałoby z przeglądu literatury przedmiotu. Nie wiadomo, czy niektóre rękopisy, szczególnie dotyczące spraw gospodarczo-majątkowych wspólnoty skasowanej formalnie na podstawie decyzji króla Prus Fryderyka Wilhelma III, nie trafiły do innych instytucji, być może do Geheimes Staatsarchiv w Berlinie, do którego przekazano akta innych klasztorów z terenu Wielkopolski ${ }^{5}$. Rozkaz gabinetowy Naczelnego Prezesa Wielkiego Księstwa Poznańskiego Edwarda Heinricha Flottwella z 31 marca 1833 wobec klarysek w Gnieźnie został zrealizowany dopiero 31 stycznia 1837 , choć konwent przetrwał w praktyce do 16 stycznia $1865^{\circ}$, gdy zmarła ostatnia klaryska i zarazem ostatnia zakonnica przebywająca w murach klasztoru (był również domem zbiorczym dla sióstr różnych zakonów z terenu Wielkopolski) - Rozalia (Tekla) Cywińska ${ }^{7}$. Do zbioru Archiwum Kapituły Metropolitalnej, w tym Biblioteki Katedralnej włączonej obecnie do AAG spuścizna zakonnic mogła trafić już kilka lub kilkanaście lat po tej dacie. Na kodeksach, dyplomach i dokumentach nie ma bowiem żadnych pieczęci czy innych

Piastowie. Leksykon biograficzny, red. S. Szczur, K. Ożóg, Kraków 1999, s. 154-161. Przybyłowicz, Reguła zakonna, s. 35 .

${ }^{4} \mathrm{O}$ księżnej jako inicjatorce fundacji wspartej finansowo przez Przemysła II M. Michalski i O.M. Przybyłowicz, M. Michalski, Błogosławiona Jolenta - refleksja historyczno-hagiograficzno-historiozoficzna, w: Franciszkanie konwentualni i klaryski w Wielkopolsce od XIII do XIX wieku, red. T. Janiak, D. Stryniak, Gniezno 2006, s. 71-82; Przybyłowicz, Reguła zakonna, s. 35.

${ }^{5}$ M. Kanior, Polityka antyzakonna władz pruskich $i$ kasata opactw benedyktyńskich $w$ Lubiniu i Mogilnie, w: Kasaty klasztorów na obszarze dawnej rzeczpospolitej Obojga Narodów i na Ślasku na tle procesów sekularyzacyjnych w Europie, t. 2, red. M. Derwich, Wrocław 2014, s. 289-298. Informacje o berlińskich zasobach tyczących skasowanych klasztorów w Wielkopolsce S. Kościelak, Sprawozdanie z kwerendy w Geheimes Staatsarchiv Preussicher Kulturbesitz w Berlinie w dniach 4-8 II 2013, „Hereditas Monasteriorum” (dalej: HM), 2 (2013) s. 496-497. Także od tego badacza usłyszałam na konferencji w Poznaniu „Losy i znaczenie dziedzictwa po klasztorach skasowanych w Wielkopolsce pod rządami pruskimi (do 1871 r.). W 180. rocznicę decyzji o likwidacji klasztorów w Wielkopolsce" informację o znajdującej się w katalogu archiwum w Berlinie pozycji Klarissen Gnesnen. Niestety nic bliższego Autor nie był w stanie powiedzieć. Na tejże konferencji wygłosiłam pierwotną, nigdzie niepublikowaną wersję referatu o kodeksach klarysek przechowywanych w AAG.

${ }^{6} \mathrm{Za}$ informację o dokładnej dacie dekretu kasacyjnego zanotowanej w Aktach kościoła Św. Trójcy w Gnieźnie odnoszącej się do zniesienia klasztoru XX Franciszkanów i Panien Zakonnych dziękuję Zbigniewowi Joskowskiemu OFMConv. W listopadzie 1836 roku wydano decyzję o kasacie klasztoru franciszkanów.

${ }^{7}$ Rozalia (Tekla - imię zakonne) Cywińska, M. Borkowska, Leksykon zakonnic polskich epoki przedrozbiorowej, t. 1: Polska Zachodnia i Pólnocna, Warszawa 2004, s. 38. Przez 29 lat, jak wynika z archiwaliów nieznanych M. Borkowskiej (AAG A. Cap. Luzy O 16, k. 6) była zakrystianką, przez dziewięć kanafarką, przez dwa furtianką i depozytarką, O.M. Przybyłowicz, Lista ksień konwentu gnieźnieńskiego XVI-XIX w., złożone do druku. 
znaków - sygnatur innych instytucji poza AKM lub/i AAG (utworzone na bazie tego pierwszego w 1960 r.), które świadczyłyby o „przejściowym” właścicielu tego zbioru. Interesujące jest to, że oprócz spuścizny rękopiśmiennej nie ma w AAG, podobnie jak w Bibliotece i Archiwum Franciszkanów w Gnieźnie książek i starodruków po klaryskach ${ }^{8}$. Ciekawe jest również to, że kodeksy liturgiczne, w tym modlitewniki, z których siostry korzystały zarówno wspólnie w chórze, refektarzu, jak i indywidualnie w celach, stanowią w zbiorze AAG zaledwie kilka pozycji. Wydaje się więc, że zakonnice św. Klary nie miały bogatego zbioru manuskryptów oraz zbiorów bibliotecznych, a korzystały z kodeksów liturgicznych i księgozbioru pobliskiego klasztoru braci św. Franciszka ${ }^{9}$. Zakonnicy sprawowali zresztą duchową opiekę nad klaryskami. Nie dziwi więc informacja odnosząca się do schyłku istnienia wspólnoty pochodząca z relacji Leona Antoniego Miaskowskiego, prepozyta katedry poznańskiej z roku 1810 . Został on wyznaczony przez biskupa poznańskiego Tymoteusza Gorzeńskiego jako delegat odpowiedzialny za sporządzenie rejestrów ruchomego majątku klasztorów w archidiecezji gnieźnieńskiej i poznańskiej zgodnie z rozporządzeniem władz Księstwa Warszawskie$\mathrm{go}^{10}$. Ksiądz Miaskowski, który osobiście sporząaził siedem raportów, a pozostałe nadzorowani przez niego dziekani wyznaczeni przez konsystorz, stwierdził, że w konwencie klarysek „biblioteka żadna nie znajduje się"11. Nie wiadomo, czy podobna sytuacja miała miejsce we wcześniejszych wiekach, czy też księgozbiór zakonnic, być może niewielki, nie uległ już wówczas rozproszeniu.

Spuścizna po klaryskach gnieźnieńskich nie stanowi w AAG wyodrębnionego zespołu. Archiwalia są rozproszone (w wyszukiwarce na stronie archiwum nie „wyskakują" żadne wiadomości po wpisaniu słowa klaryski) w kilku zespołach: Zakon Klarysek w Gnieźnie (ZKG), Dyplomy Gnieźnieńskie (Dypl.Gn), dział Akta klasztorne, Archiwum Kapituły Metropolitalnej (A. Cap. B) oraz akta luźne (A. Cap. Luzy O sygn. 14-52), w końcu Konsystorz gnieźnieński. Całość obejmuje oryginalne pergaminowe dyplomy średniowieczne i nowożytne, dokumenty papierowe z XVI-XIX wieku, kodeksy liturgiczne w tym cenny, znany z literatury

\footnotetext{
${ }^{8}$ Takich informacji nie przyniosła dotychczasowa, kilkuletnia kwerenda w zbiorach starodruków prowadzona ramach grantu kierowanego przez dr Piotra Pokorę (Uniwersytet im. A. Mickiewicza w Poznaniu): Inwentaryzacja zasobu Biblioteki Katedralnej w Gnieźnie, NPRH nr 11H 120179 81. Za informację dziękuję zaangażowanemu w ten projekt mgr Michałowi Muraszce.

${ }^{9}$ Z. Joskowski nie wymienia żadnych pozycji należących w przeszłości do klarysek w zestawieniu starodruków znajdujących się w Bibliotece Prowincjalnej franciszkańskiej w Gnieźnie, Z. Joskowski OFMConv., Stare druki z księgozbiorów klasztornych w zbiorach Biblioteki Prowincjalnej Franciszkanów w Gnieźnie. Apendyks do katalogu starych druków, „HM”, 5 (2014) s. 303-327.

${ }^{10} \mathrm{~K}$. Kłudkiewicz, Spisy i katalogi wielkopolskich bibliotek klasztornych z klasztorów skasowanych w Wielkopolsce pod rzadami Prus do połowy XIX w. - charakterystyka i znaczenie, „HM”, 6 (2015) s. 101-142, tu. s. 105-106.

${ }^{11}$ Tamże, przyp. 30.
} 
przedmiotu, piętnastowieczny iluminowany antyfonarz ${ }^{12}$ oraz o tematyce gospodarczo-ekonomicznej, a przede wszystkim akta luźne ${ }^{13}$.

W Gnieźnie zachowało się 27 kodeksów, w tym sześć w zespole Zakon Klarysek w Gnieźnie (ZKG obejmuje siedem jednostek). Pozostałe umieszczono głównie w AAG A. Cap. B, zaś pojedyncze znajdują się w innych lokalizacjach. W tym miejscu wspomnieć należy jeszcze o jednym - Processus Causa Canonizacionis Jolendae $1776 \mathrm{w}$ języku łacińskim i polskim ${ }^{14}$ oraz XIX-wiecznych poszytach, które nie mają proweniencji klasztornej, ale związane $\mathrm{z}$ historią konwentu, a do tej pory nie były w zasadzie zauważone przez literaturę przedmiotu. Processus był przygotowany zapewne na prośby zakonnic, a być może i franciszkanów w celu rozpoczęcia starań o wyniesieni Jolenty na ołtarze. Obecnie pomieszczony jest w zespole Akta Konsystorza Generalnego. Natomiast wspomniane poszyty znajdują się w zespole Archiwum Kurii Metropolitalnej A. Cap. II - to akta konsystorza generalnego biskupiego poznańskiego tyczące się kasacji klasztoru, jak nazwano wspólnotę ,panien franciszkanek” w Gnieźnie ${ }^{15}$. Zawierają pisma urzędowe związane z procesem kasat i zarządzaniem majątkiem poklasztornym, ale też korespondencję zakonnic do osób świeckich i duchownych. Akta wciągnięte do tychże podszytów są pisane głównie w języku niemieckim, częściowo tylko w polskim.

Przechodząc do analizy zbiorów rękopiśmiennych wypada zacząć od najstarszych.

To trzy dyplomy pergaminowe wystawione przez ksienie w imieniu klasztoru - jeden z 1371 roku przez Staszkę, a dwa w XVII stuleciu przez ksienie Dorotę Bromirską w 1617 roku i Katarzynę Jarkuszewską w 1637 roku$^{16}$.

${ }^{12}$ I. Pawlak, Graduat klarysek gnieźnieńskich z 1418 roku jako dokument kultury muzycznej Gniezna, „Nasza Przeszłość”, 24 (1966) s. 135-141; A. Moszczyńska, Graduał klarysek gnieźnieńskich ms.170 z Biblioteki Katedralnej w Gnieźnie, Warszawa 1988, maszynopis w Bibliotece Uniwersytetu Kardynała Stefana Wyszyńskiego w Warszawie.

${ }^{13}$ O.M. Przybyłowicz, Archiwalia klarysek gnieźnieńskich w Archiwum Archidiecezji Gnieźnieńskiej, cz. 1: Sprawozdanie z kwerendy w dniach 29-31 VIII 2012 r., „HM”, 1 (2012) s. 456462; eadem, Archiwalia klarysek gnieźnieńskich w Archiwum Archidiecezji Gnieźnieńskiej, cz. 2: Sprawozdanie z kwerendy $w$ dniach 9-12 VII 2013 r., „HM”, 3 (2013) s. 552-569. Zestawienie akt także J. Mizerka, Archiwalia poklasztorne, urzędowe, kasacyjne i pokasaycjne w zasobie Archiwum Archidiecezjalnego w Gnieźnie (klasztory powstałe i/lub skasowane przed 1850 r.), „HM”, 6 (2015) s. 163-236, dane w tabeli o klaryskach, s. 182-191.

${ }^{14}$ AAG Akta Konsystorza sygn. G VII 2. Kart numerowanych 259, ostatnie cztery bez numeracji. Zawiera zeznania zakonnic i osób świeckich na temat kultu Jolenty, dokumenty publiczne i prywatne ad causam B. Jolentae vidue ordinis Sanctae Clarae [...] ex archivio monialium S. Clarae Gnesnensis, ponadto listę cudownych wydarzeń związanych z fundatorką i dokumenty oraz wypisy $\mathrm{z}$ różnych akt.

${ }^{15}$ AAG sygn. AKM II 39/4, nlb. [91], bez inwentarzy (1835-1867); sygn. AKM II 39/6, k. 10 Sprzedaż pomieszczenia nad zakrystią klarysek (1885-1886).

${ }^{16}$ Pierwszy drukowany KDW. t. 3 nr 1647, dwa z XVII wieku: Dypl. Gn. nr 867: Dorota Bramierska! [Bromierska] ksieni z konwentem, w tym imiennie wymienionymi pięcioma zakonnicami nadaje Wojciechowi Płotce młynarzowi klasztoru młyn w Piszczu i drugi w Korzeczniku pod pewnymi warunkami; Dypl. Gn. nr 886: Ksieni Katarzyna Obediencja Jarkuszewska wraz z konwentem 
Zachowało się też 158 dokumentów papierowych z XVII-XIX wieku w zespole AAG A. Cap. Luzy O 14-52 (Klaryski Gniezno) liczącym 2500 akt i ponad 4000 kart wystawionych przez klasztor lub/i ksienie w imieniu konwentu, a także zwykłą zakonnicę (jeden). To przede wszystkim akta o charakterze gospodarczym i ekonomicznym - nadania, ugody, dzierżawy, skwitowania oraz listy ${ }^{17}$. Wspólnota była również odbiorcą dokumentów, w tym łask królewskich - w tymże zespole znajdują się 23 oryginalne przywileje władców polskich, począwszy od Zygmunta Starego, a skończywszy na Stanisławie Auguście Poniatowskim, uwierzytelnione pieczęciami oraz podpisami monarchów bądź pracowników kancelariii ${ }^{18}$.

Uwagę w niniejszym artykule chcę jednak skupić na najbardziej różnorodnej grupie w spuściźnie archiwalnej klarysek w AAG - manuskryptach. Można wyróżnić w niej trzy kategorie tematyczne kodeksów: prawno-normatywne, czyli reguły i konstytucje (dwa egzemplarze) ${ }^{19}$, liturgiczne (proweniencja dwóch jest pewna $^{20}$, trzy kolejne zostały przypisane przez Jadwigę Rył zakonnicom z Gniezna) ${ }^{21}$ oraz rachunkowo-gospodarcze. Ta ostatnia grupa jest najliczniejsza. Obejmuje dziesięć ksiąg expensów illub perceptów konwentu począwszy od najstarszej z 1613 r. Trzy z nich umieszczono w zespole ZKG, a siedem w zespole A. Cap. $\mathrm{B}^{22}$. Zachowało się ponadto dziewięć archiwaliów (ksiąg lub poszytów) z drugiej

w tym sześcioma wymienionymi zakonnicami nadaje Adamowi Rajowi sołectwo w Woźnikach. Przybyłowicz, Archiwalia klarysek, cz. 2.

${ }^{17}$ O.M. Przybyłowicz, Dyplomy i akta klasztoru klarysek w Gnieźnie. Charakterystyka zbioru i sposoby uwierzytelniania w praktyce konwentu zakonnic św. Klary, oddane do druku.

${ }^{18}$ O.M. Przybyłowicz, Documents of Polish kings issued for the monastery of the Poor Clares in Gniezno (16th-18th centuries). Kings as the protectors of the convent, w: Orden und Stadt, Orden und ihre Wohlthäter. Monastica historia 4, red. J.M. Havlík, J. Hlaváčková, K. Kollermann, Prag St. Pölten 2019, s. 463-483

${ }^{19}$ AAG ZKG 1 Reguły i konstytucje 1593-1640; sygn. ZKG 2 Reguła zakonu Klary świętej i konstytucje klasztoru gnieźnieńskiego 1603-1759.

${ }^{20}$ AAG BK Ms 170 Antyfonarz; AAG A. Cap. B 802 Modus suscipiendi novitias ad habitum S. Clarae Gnesnen(sis), 1600, k. 12 (dalej cyt. AAG, Modus 1600). O. M. Przybyłowicz, „Pamięć obłóczyn kożdy probantki”. Ceremonia obłóczyn w świetle rękopisu Modus suscipiendi novitias ad habitum S. Clarae z 1600 r. z klasztoru klarysek gnieźnieńskich, „HM”, 3 (2013) s 179-194.

${ }^{21}$ J. Rył, Katalog rękopisów biblioteki katedralnej w Gnieźnie, Lublin 1982. AAG BK Ms 131 Rozmyślania i różne modlitwy. Modlitewnik klarysek z Gniezna, łac. i pol. XVI/XVII w.; AAG BK Ms 249 Antyfonarz klarysek gnieźnieńskich, łac. XVII w. zachowanych pięć kart; AAG BK Ms 250 Funebrale. Ceremoniał pogrzebowy klarysek z Gniezna, łac. i pol. XVII w. Analiza tego ostatniego O. M. Przybyłowicz, Z badań nad obrządkiem pogrzebowym klarysek - liturgia i miejsca pochówku w klasztorach na ziemiach polskich, w: Epigraphica et Sepulcralia, t. 6, ed. J. Roháček, Praha 2015, s. 201-224.

${ }^{22}$ AAG ZKG 5 Regestr rozchodowy klasztoru gnieźnieńskiego zakonu s. Klary, który po pogorzeniu tegoż klasztoru poczyna się w tym że roku 1613 (do 1655); AAG ZGK 6 Regestr wziątków i wydatków w konwencie gnieźnieńskim 1701-1730; AAG ZKG 7 Regestr wziątków i wydatków w konwencie gnieźnieńskim 1730-1755. W zespole AAG A. Cap. B: sygn. 804 Regestra wziątków konwentu gnieźnieńskiego W. PP. Zakonnic S.M. Klary 1666 do 1678; sygn. 805 Regestra wziątków konwentu gnieźnieńskiego W. P. Zakonnic S.M. Klary 1679-1689; sygn. 806 Regestra wziątków konwentu gnieźnieńskiego W. PP. Zakonnic S.M. Klary 1691-1701; sygn. 807 Regestra wziątków konwentu gnieźnieńskiego W. PP. Zakonnic S. M. Klary 1765-1772; sygn. 808 Regestra wziątków 
połowy XVIII w. stanowiących rozliczenia finansowe konwentu z miastem klasztornym Kostrzynem, jak np. Regestra percepty i expensy piwa, gorzałki, pieniądzy z prowentu za mości Pana Macieja Noskowskiego ekonoma kostrzyńskiego poczynające się roku pańskiego 1783 dnia 24 czerwca oraz obrachunki z poddanymi z jednej spośród wsi klasztornych - Oborą (także w zespole A. Cap. B) ${ }^{23}$.

Zaliczam także do tej grupy niezwykle cenny, najstarszy, pochodzący z $1593 \mathrm{r}$. zatytułowany: Regestrum censuum de bonis Monialium S. Clarae Gnesnensis ${ }^{24}$. Zawiera on szczegółowe informacje zarówno na temat poddanych konwentu, jak i danin i należności pobieranych przez klasztor.

W powyższej klasyfikacji nie mieści się kolejny kodeks przypisany w katalogu AAG do zespołu ZKG zatytułowany: „Księgi wszystkich spraw konwentu gnieźnieńskiego zakonu S. Klary. To jest katalog wszystkich sióstr zakonnych w tym klasztorze od pamięci ludzkiej professowanych żywych i zmarłych. Przytem inwentarz wszystkich dóbr prowentów także i przywilejów tegoż klasztoru za urzędu Wielebnej w Chrystusie Panny, Panny Doroty Bromierskiej, na ten czas Księniej tegoż klasztoru (acz niegodnej) uczynione, i pilnie pisane w roku pańskim 1609 "25. Ponieważ w osobnym artykule omówiłam zawartość tego niezwykle cennego rękopisu papierowego mającego 802 strony (na których znajduje się dukt kilkudziesięciu rąk) to ograniczę się tylko do najważniejszych informacji o tym zabytku ${ }^{26}$. Spisywanie kodeksu rozpoczęto w 1609 r. za rządów ksieni Doroty Bromirskiej, której elekcja odbyła się właśnie w tym roku. To wydarzenie wskazuje na nią jako inicjatorkę założenia księgi prowadzonej następnie do 1865 roku $^{27}$. Księga reprezentuje częsty w piśmiennictwie klasztornym epoki nowożytnej mieszany typ przekazu, łączący w sobie cechy kroniki, rocznika, katalo-

konwentu gnieźnieńskiego W. PP. Zakonnic S. M. Klary 1772-1786; sygn. 809 Regestra wziątków i wydatków konwentu gnieźnieńskiego W. PP. Zakonnic S.M. Klary 1790-1798; sygn. 812 Regestrum censuum de bonis Monialium S. Clarae Gnesn.(ensis) 1593.

${ }^{23}$ AAG A. Cap. B: sygn. 810 Dekreta sądów wiecowych w Kostrzynie na rzecz klarysek w Gnieźnie 1752-1783, sygn. 811 Dekreta nadworne miasta Kostrzynia 1775-1786; sygn. 813 Percepta de Kostrzyn et Expensa 1774-1775; sygn. B 814 Regestra wszelkiej percepty i ekspensy prowencie kostrzyńskim zaczynają się od dnia 22 czerwca 1780 a kończą się dnia 30 kwietnia roku 1783; sygn. 815 Regestra percepty i expensy piwa, gorzałki, pieniądzy z prowentu za mości Pana Macieja Noskowskiego ekonoma kostrzyńskiego poczynające się roku pańskiego 1783 dnia 24 czerwca; sygn. 816 Regestra wszelkiej krescencyi i percept jako aż i expensy wszelkiej na folwarkach Kostrzynie i Stronianach zaczynający się w roku 1783 dnia 30 czerwca kończący się w roku 1784 dnia 24 czerwca; sygn. 817 Regestra prowentu kostrzyńskiego 1786 a die 11 julii przychodu i wydatku; sygn. 818 Regestra oborskie 1780-1781; sygn. 819 Regestra zbóż z Obory tak percepty jako i expensa w roku 1783.

${ }^{24}$ AAG A. Cap. B 812. Jest obecnie przedmiotem moich badań i analiz.

${ }^{25}$ AAG ZKG 3 (dalej: Księgi 1609). Za jej udostępnienie zarówno w oryginale, jak i kopii na CD dziękuję dyrektorom archiwum śp. ks. Marianowi Aleksandrowiczowi, który okazał mi wiele serdeczności i pomocy podczas pierwszych badań w 2000 roku, także obecnemu ks. Michałowi Sołomieniukowi.

${ }^{26}$ O. M. Przybyłowicz, Rękopis Księgi wszystkich spraw Konwentu Gnieźnieńskiego zakonu S. Klary [...] pilnie pisane w roku pańskim 1609 i jego zawartość, „HM”, 7 (2016) s. 247-263.

${ }^{27}$ M. Borkowska, Leksykon, s. 27. Przed tym jak została ksienią była wikarią od 1596, Przybyłowicz, Lista ksień. 
gu i nekrologu sióstr oraz wykaz i opis dóbr - inwentarze majętności. Zbliżony charakter ma na przykład znany mi z autopsji kodeks powstały $\mathrm{w}$ tymże stuleciu (1681 r.) w klasztorze klarysek w Starym Sączu ${ }^{28}$. Pojawienie się tego typu źródeł wiązało się z rozwijającą od końca XVI stulecia w klasztorach żeńskich Rzeczypospolitej twórczością kronikarską wynikającą z postępu alfabetyzacji społeczeństwa nowożytnego, ale również zaleceń Kościoła, w tym biskupów, którzy po soborze trydenckim objęli pieczę nad większością zgromadzeń kobiecych ${ }^{29}$.

Informacje w tym cennym kodeksie gnieźnieńskiej wspólnoty można podzielić na kilka tematycznych kategorii. Wśród nich najcenniejsze są, moim zdaniem, dane mogące posłużyć do badań prozoprograficznych, co uczyniła M. Borkowska oraz gospodarczych. Odnosząc się do tych pierwszych - kodeks prezentuje dwa katalogi profesek, dwuczęściowy, prowadzony na bieżąco, z wykorzystaniem niezachowanych obecnie źródeł, obejmujący lata $1562-1794^{30}$ oraz niepełny, spisany w 1763 r., z kilkoma informacjami wpisanymi później trzema różnymi rękoma, obejmujący lata $1613-1774^{31}$; dwuczęściowy, prowadzony na bieżąco nekrolog sióstr zmarłych w latach 1567-1840 ${ }^{32}$; księgę obłóczyn i profesji z lat 1718-1794 r.; opisy elekcji 30 ksień (z lat 1685-1825); wykazy nowych urzędniczek mianowanych przy okazji instalowania nowej przełożonej (od 1768 r.) ${ }^{33}$, ponadto kopie akt gospodarczych, w których również pojawiają się poszczególne zakonnice. Jak widać w literaturze, M. Borkowska nie przeanalizowała dokładnie tych ostatnich grup. Wszystkie informacje w połączeniu ze zgromadzonymi dokumentami w AAG A. Cap. Luzy O 14-52 (do których M. Borkowska nie dotarła) pozwalają skorygować lub uzupełnić dane zestawione przez nią w Leksykonie zakonnic w odniesieniu dla wspólnoty gnieźnieńskiej.

Około połowa informacji w Księdze 1609 dotyczy natomiast spraw ekonomii i gospodarki klasztoru, są to m.in. inwentarze dóbr zwane w nomenklaturze zakonnej rewizjami, począwszy od 1610 r., najszczegółowsza w 1615 r. oraz kolejne $\mathrm{z}$ lat $1624,1627,1631,1632,1661,1667,1673,1676,1682,1685,1686^{34}$. Tej tematyki dotyczy także treść dokumentów - oryginałów, kopii i odpisów wciągniętych na karty rękopisu, z których większa część jest zachowana w AAG A. Cap.

\footnotetext{
${ }^{28}$ Archiwum Klasztoru Klarysek w Starym Sączu, sygn. Gr/a-1, s. 3: Księga przywilejów, zapisów rocznych, intercyz Konwentu Starosądeckiego Reguły S. Klary fundaciej Błogosławiony Kunegundy Matki i fundatorki naszej na pamiątkę wieczną z różnych przywilejów pargaminowych i extraktów zapisanych [a]ntycznych wiernie wyjętych dla których lepszy pewności księgę tą przy przyciśnięcia pieczęci klasztorny rękami naszemi podpisałyśmy, działo się Roku Pańskiego 1681 dnia $20 \mathrm{M}[$ iesią]ca Lipca.

${ }^{29}$ Zob. M. Borkowska, Latanie pamięci (czyli rzecz o klasztornym kronikarstwie retrospektywnym), „Znak”, t. 47, 1995, s. 103-110; eadem, Życie codzienne polskich klasztorów żeńskich w XVII i XVIII wieku, Warszawa 1997, s. 326; K. Targosz, Piórem zakonnicy. Kronikarki w Polsce XVII w. o swoich zakonach i swoich czasach, Kraków 2002; A. Szylar, Kronika bernardynek lubelskich 1618-1885 (Towarzystwo Naukowe Katolickiego Uniwersytetu Lubelskiego, Źródła i Monografie, 353; Prace z Historii Szkolnictwa i Opieki Społecznej w Polsce, 3), Lublin 2009.

${ }^{30}$ AAG ZKG 3 Księgi 1609, s. 101-128, lata 1562-1718, s. 186-204, lata 1718-1794.

${ }^{31}$ Tamże, s. 430-435. W większości wypadków podane daty zgonów.

${ }^{32}$ Tamże, s. 129-165, lata 1567-1756, s. 172-185, lata 1756-1840.

${ }^{33}$ Tamże, s. 186-204.

${ }^{34}$ Przygotowują ich część do edycji.
} 
Luzy O $14-52^{35}$. Niektóre z nich to również ciekawostki obyczajowo-społeczne, jak np. suplika z 1705 roku spisana w imieniu ubogiego młynarza Wawrzyńca Jarzębińskiego, poddanego sióstr św. Klary ${ }^{36}$. Prosił on zakonnice o naznaczeniu placu na postawienie wiatraka, domostwa, stodoły, obory, chlewu z podwórzem, przyznanie ogrodu, ról i wolnizny na 20 lat

przy wyściu zaś tego mego wolnego zażywania, gdy będą ody mnie odbierać te dobra, abym sto tynfów consolaciej odebrał z ręki moich Wielebnych Ich Mości Panien, przy której suplice sam się do nóg rzuciwszy zostawam niegodnym $[\ldots]$

Pod tekstem supliki wpisanej zapewne przez pisarza bądź prokuratora konwentu znajduje się własnoręczny podpis ksieni, uczyniony dość niewprawną ręką: „Salomeya Weloweska X G"37.

Dane o realiach życia codziennego w nowożytnej klauzurowej wspólnocie przynoszą natomiast recesy wizytacji przełożonych franciszkańskich oraz opisy elekcji ksień, a także charakterystyki zakonnic towarzyszące wpisom o ich śmierci, jak np. o ostatniej ksieni Salomei Brzechwiance ${ }^{38}$.

Niewiele wpisów dotyczy spraw pozaklasztornych - za wyjątkiem kontaktów zakonnic z braćmi zakonu św. Franciszka z Gniezna oraz hierarchami kościelnymi. Te informacje tak czy inaczej były powiązane $z$ losami zakonnic. W jednej z nich z 17 stycznia 1739 odnotowano pogrzeb w Tumskim kościele, czyli katedrze, prymasa Teodora Potockiego, arcybiskupa gnieźnieńskiego, zaś w tym samym dniu ochrzczono w kaplicy klarysek dziewięcioletnią Żydówkę ${ }^{39}$. Zarejestrowano też wizytę arcybiskupa Ignacego Raczyńskiego w Gnieźnie w 1810 r. ${ }^{40}$ Inne zapisy splatają dzieje miasta i konwentu - to wpisy o pożarach: w roku 1613 „Wspomnienie ognia gnieźnieńskiego” oraz podobnego żywiołu z $1707 \mathrm{r}^{41}$. Z kolei w roku 1655 znalazł się lakoniczny wpis o potopie szwedzkim, kontrybucjach płaconych przez klasztor i zniszczeniach jego dóbr ${ }^{42}$. Spustoszenie w majątkach konwentu i w całym państwie przynosiły też, oprócz nieprzyjacielskich wojsk, klęski żywiołowe: „w lipcu deszcze gwałtowne długo padały w polach po całej Polsce zboża, łąki i ogrody pozalewały [...]”. Innych szkód dokonały wojska rosyjskie przebywające podczas elekcji Augusta III oraz... myszy

${ }^{35}$ O.M. Przybyłowicz, Zajac, dwa złote na pieprz i kary za gry hazardowe. Dwa przywileje klarysek dla miasta Kostrzyna z 1477 i 1615 r., w: Ecclesia Regnum Fontes. Studia z dziejów średniowiecza. Prace ofiarowane Profesor Marii Koczerskiej, Warszawa 2014, s. 138-149.

${ }^{36}$ AAG ZKG 3 Księgi 1609, s. 359.

${ }^{37}$ Borkowska, Leksykon, s. 32 Marianna (Salomea) Wielowiejska.

${ }^{38}$ Przybyłowicz, Księgi 1609, s. 248. Nepomucena (Salomea), Borkowska, Leksykon, s. 38 bez podania innych urzędów. Była również kantorką, szafarką, furtianką, zakrystianką, mistrzyni nowicjatu, depozytorską, AAG A. Cap. Luzy O 16. k. 6, Przybyłowicz, Lista ksień.

${ }^{39}$ AAG, Księgi 1609, s. 55.

${ }^{40}$ Tamże, s. 569: „1810 dnia 5 maja Jaśnie Oświecony Xiąże Jego Mość Ignacy z Raczyna i Małoszyna Raczyński Arcy-Biskup gnizinski [sic] i Administrator Diecezyi Warszawski tu stanąwszy w Gnieźnie".

${ }^{41}$ Tamże, s. 246-251, 251-253. Dwoma różnymi rękami, więc pisane w XVII i XVIII w.

${ }^{42}$ Tamże, s. 752 relacja o wtargnięciu Szwedów, kontrybucjach i spustoszeniu dóbr klasztoru. 
[..] byli półtrzecia roku, i tandem ustąpili z Polski, lecz myszy z pól do stodół przystąpiły szkody wielkie robiły, potym srogość nastąpiła głód i chorobska cieszkie na ludzie dla czego wiele ludu wszelkiej kondycyji wymarło w roku 1736 i w 1737 w tym roku ${ }^{43}$.

Przechodząc do dalszej analizy zawartości źródeł rękopiśmiennych klarysek w Gnieźnie i prezentacji możliwości badawczych, wypada stwierdzić, iż najbardziej jednolite pod względem spójności tematycznej i informacyjnej są kodeksy rachunkowe oraz liturgiczne. Natomiast w obydwu księgach zawierających normy prawne zgromadzenia św. Klary znajdują się nie tylko tytułowe reguły zakonne oraz konstytucje $\mathrm{z}$ lat $1593{ }^{44} \mathrm{i} 1603 \mathrm{w}$ redakcji z $1651 \mathrm{r} .{ }^{45}$, ale i wpisy o innym charakterze, dość różnorodne, lecz stanowiące wyrywkowe informacje. To oraz ich stan zachowania (o czym dalej) nie stwarza tak dobrej perspektywy badawczej jak w przypadku opisywanych wyżej źródeł gospodarczo-rachunkowych.

Analiza kodeksów rachunkowych i licznych rozliczeń (poszyty, luźne akta) z poddanymi miasta Kostrzyna oraz wsi należących do zakonnic pozwoli w przyszłości nie tylko na poznanie realiów codzienności wspólnoty poprzez wgląd w listę wydatków i dochodów, ale również na podjęcie badań nad funkcjonowaniem nowożytnej gospodarki zgromadzeń zakonnych, o czym w literaturze przedmiotu można znaleźć stosunkowo niewiele informacje (najwięcej w przypadku cystersów), zaś w odniesieniu do Gniezna praktycznie nic ${ }^{46}$. Najstarsza księga rachunkowa rozpoczynająca się, jak już wspomniano, w 1613 r. za urzędowania ksieni Bromirskiej prowadzona była z przerwami do $1655 \mathrm{r}$. Jej pewną niedoskonałością jest to, że znalazły się w niej wyłącznie informacje o wydatkach wspólnoty ${ }^{47}$. Kolejne, począwszy od 1666 r. pisane były synchronicznie - obustronnie i za-

${ }^{43}$ Tamże, s. 791.

${ }^{44}$ AAG ZKG 1 Reguły, k. 35r: Zebrane cześcią s Conciliūm Tridenskiego częścią s statutów kapituły główny florenskij od najwyższe(go) Papieza Piusa czwartego wybranych y utwierdzonych [na marginesie rubrą: skąd i przes kogo są zebrane te Constitucje] Napisane i dane przez Wielebnego Ojca Jerzego Benignussa de Doionis Beluvenae pisma s. Doctora zakonu S. Franciszka, we wszystkiej Prowinciej Polskiej nawyszego P. Comissarza, dla poprawy y zachowania panien zakonnych. S. Clary Panny Mariej w Gnieźnie, Zakonu S. Franciszka, które od tychże Panien pod karaniem, na tychże Constituciach napisanym statecznie mają być zachowane.

${ }^{45}$ AAG ZKG 2 Reguła zakonna, k. 5r-47v

${ }^{46}$ Wiele zagadnień poruszono na konferencji „Klasztor w gospodarce średniowiecznej i nowożytnej. Dyskusja, szczególnie burzliwa w pierwszym i ostatnim dniu obrad ukazała, jak wiele pól tej tematyki jest jeszcze niedostatecznie poznanych lub nieodkrytych. Klasztor w gospodarce średniowiecznej i nowożytnej, red. M. Derwich, Wrocław 2013; D. Burdzy, „Percepta i expensa”. Budżety obu klasztorów dominikańskich w Sandomierzu w XVII w., w: Klasztor w gospodarce, s. 319-332; P. Gąsiorowska, Obrót gotówka w klasztorze żeńskim na przyktadzie osiemnastowiecznych ksiag rachunkowych wybranych klasztorów krakowskich i lwowskich, w: Klasztor w gospodarce, s. 303318; O.M. Przybyłowicz, Jak panny zakonne rozliczaty się? Księgi rachunkowe jako źródto do badań nad polskimi klasztorami żeńskimi w XVI-XVIII w., w: Klasztor w gospodarce, s. 101-114; A. Szylar, „Sprawa o tym jak benedyktynki gospodarstwo prowadzity”. Organizacja i funkcjonowanie gospodarki opactwa benedyktynek w Sandomierzu w XVII $i$ XVII w., w: Klasztor w gospodarce, s. 447-460.

${ }^{47}$ AAG ZKG 5 Regestr 1613 (do 1655). 
wierają wpisy zarówno o expensach, jak i perceptach w określonym przedziale chronologicznym. Każda księga obejmują okres rozrachunkowy od dziesięciu ${ }^{48}$ do maksymalnie 29 lat ${ }^{49}$. W każdym kodeksie można wyróżnić od kilku do kilkunastu rąk pisarskich. $Z$ lat 1666-1786 z przerwą na niespełna dekadę (1756-1764) zachowały się kompletne informacje o dochodach i przychodach klasztoru klarysek w Gnieźnie, ich strukturze, specyfikacji, a także pośrednie dane pozwalające określić liczebność zgromadzenia. Wiadomości z końca XVII stulecia można skorelować z informacjami zawartymi we wcześniej wymienianych rewizjach-inwentarzach $\mathrm{z}$ lat siedemdziesiątych i osiemdziesiątych tego stulecia znajdujących się w AAG Księgi 1609. Zachowały się także fragmenty późniejszej buchalterii klasztornej z samego końca XVIII stulecia ${ }^{50}$.

Cenne są w rachunkach nie tylko informacje o świecie rzeczy oraz cenach, ale i również inne dane o wspólnocie. Po pierwsze podpisy zakonnic pozwalają na weryfikację danych prozopograficznych, zestawienia i rozliczenia budżetowe zaś czynione przez wizytatorów uwierzytelniane ich pieczęciami ukazują zagadnienie nakreślone przez M. Borkowską pod trafnym tytułem jednego z rozdziałów jej monografii: „Jak się panny gospodarstwem bawiły”51 i stan dochodowości gospodarki konwentu. Wizytatorzy na kartach przychodów dokonywali bowiem zawsze zestawienia expensów i perceptów, zapisując obydwie pozycje i informując o dodatnim lub ujemnym bilanse w porównaniu do ostatniej swej bądź poprzednika wizyty. Wpisy zwracają także uwagę na problem nadzoru - zarządzania gospodarką żeńskich klasztorów przez męskich zwierzchników, jak to ujmowała w swych badaniach M. Borkowska, podążając za terminologią źródeł nowożytnych. Rachunki zawierają informacje o częstotliwości wizytacji, a więc pokazują funkcjonowanie zakonu św. Franciszka oraz formy kontroli nad majątkiem i dobrami żeńskiej wspólnoty.

Cennym źródłem do poznania funkcjonowania gospodarki klarysek jest wspomniany już Regestrum censuum z 1593 r. Na dziesięciu kartach (ma w sumie 15 kart bez oprawy) spisano po polsku, nie zaś w łacinie jak sugeruje tytuł, powinności poddanych z miasta Kostrzyna oraz wszystkich wsi klasztornych. Na tym przykładzie widać, że rozliczenia $\mathrm{z}$ poddanymi zachowane $\mathrm{w}$ formie poszytów lub luźnych kart z XVIII stulecia, czynione były i we wcześniejszych wiekach

${ }^{48}$ AAG A. Cap. B 805 Regestra 1679-1689; sygn. A. Cap. B 806 Regestra 1691-1701.

${ }^{49}$ AAG ZGK 6 Regestr 1701-1730.

${ }^{50}$ AAG A.Cap. B 809 Regestra 1790-1798 zawierają niestety tylko cztery karty. Można przypuszczać, że był to rękopis z lat 1786-1798, z którego zachowały się jedynie te fragmenty. Poprzednia księga AAG ACap. B 808 kończy się bowiem w czerwcu 1786.

${ }^{51}$ AGG. A Cap. B 804 Regestra 1666-1678, np. k. 2v podpisy: Katarzyna Klonowska ksieni, Elżbieta Nowowiejska wikaria, Katarzyna Chwałkowska, Anna Ciągnowska, Salomea Węgierska, Agata Jedlecka, Apolinara Mierzwińska, k. 153 r pieczęć opłatkowa prowincjała Kazimierza Biernackiego. Borkowska, Leksykon, s. 28-29: Katarzyna (Eustochia) Klonowska/Kłunowska, Elżbieta (Emilia) Nowowiejska bez urzędu, Katarzyna (Pacjencja) Chwałkowska/Chwalikowska, Salomea Węgierska, Agata Jedlecka, Barbara (Apolinara) Mierzwińska/Mierzwieńska, Ciągnowska nie występuje wśród zakonnic wymienionych w Leksykonie. Borkowska, Życie codzienne, s. 162. 
w formie pisemnej i podobnie mogło się dziać nawet w średniowieczu ${ }^{52}$. W źródle z końca XVI w. podano areał uprawnej ziemi, zobowiązania i świadczenia mieszkańców. W przypadku Kostrzyna było to podworowe, kucharskie i szos. Ponadto zapisano w nim liczbę poddanych zamieszkujących wsie klasztorne oraz indywidualne daniny w naturaliach przekazywane konwentowi w określone dni roku. We wsiach odnotowano ponadto liczbę żywego inwentarza oraz opisano niejednokrotnie stan budynków gospodarczych. Jedną z danin był słód oddawany przez kostrzynian, bowiem w miasteczku znajdował się: „Młyn słodowy koński $\mathrm{z}$ którego do konwentu miary słodowe przychodzą z których konwent ma w piwie opatrzenie $^{53}$ ". Jego mieszkańcy musieli też przekazywać klaryskom na Boże Narodzenie „na pieprz groszy trzydzieści i sześć”. Dokładność i precyzja różnorodnych danych, wśród których nie zabrakło nawet imion kmieci z poszczególnych dóbr, wskazuje na to, że przykładano znaczenie do spraw gospodarczych i majątkowych. Wydaje się, że uwaga ta może dotyczyć kilku grup - zwierzchników zakonnych wizytujących klasztor, urzędników Ubogich Panien, w końcu choć być może w mniejszym stopniu, samych zakonnic. Znakomitym porównawczym materiałem dla powyższego źródła są rewizje z XVII stulecia, szczególnie najobszerniejszy, mający ponad 30 stron z 1615 r., pomieszczone w rękopisie AAG Księgi $1609^{54}$.

Nieco inny charakter mają rozliczenia roczne, maksymalnie trzyletnie czynione z poddanymi poszczególnych wsi klarysek oraz mieszkańcami miasteczka należącego do zakonnic - Kostrzyna. Pochodzą one wyłącznie z drugiej połowy XVIII w., ale można również przypuszczać, że podobne zapisy prowadzone były i we wcześniejszych latach. Być może dokumentacja nie była po prostu gromadzona i zachowywana $\mathrm{z}$ taką pieczołowitością ze względu na fakt, iż czyniona była w tak krótkim okresie i miała charakter doraźny. Nie można jednak wykluczyć, że archiwalia tego typu uległy zniszczeniu jeszcze w okresie funkcjonowania klasztoru do początku XIX wieku, gdy klaryski nie czerpały już dochodów $\mathrm{z}$ majętności przejętych przez władze pruskie lub też zostały zabrane przez administrację pruską, a następnie uległa rozproszeniu i zniszczeniu.

Szczegółowe, żmudne badania, szczególnie kodeksów rachunkowych najpierw cząstkowe (odczytanie danych, wprowadzenie do komputera, opracowanie bazy danych), a następnie syntetyczne (zestawienie danych z poszczególnych lat), których podjąć może się tylko zespół, nie zaś jedna osoba, pozwolą na poznanie kwestii zarządzania majątkiem, kondycji finansowej od końca XVI stulecia do końca XVIII wieku, a ponadto sposobu funkcjonowania klasztoru w gospodarce miejskiej i społeczeństwie Gniezna epoki nowożytnej. Dopiero tak drobiazgowa analiza sprawi, że będzie można udzielić odpowiedzi na wiele pytań dotyczących

${ }^{52}$ Takie rozliczenia zachowały się z terenu ziem polskich dla klasztoru kanoników regularnych w Kłobucku, Biblioteka PAN w Krakowie, Księga rachunków gospodarczych klasztoru kanoników regularnych w Kłobucku z lat 1446-1518.

${ }^{53}$ AAG A. Cap. B 812, k. 1.

${ }^{54}$ O.M. Przybyłowicz, Źródła do poznania gospodarki $w$ dobrach wiejskich klarysek gnieźnieńskich od końca XVI do schyłku XVII stulecia, „Kwartalnik Historii Kultury Materialnej” (dalej: KHKM), 65 (2017) nr 4, s. 447-460. 
gospodarki klasztornej: dochodowości dóbr, bilansowania budżetu, struktury perceptów $i$ expensów. Pozwoli także na wskazanie różnic bądź podobieństw w funkcjonowaniu wspólnoty w długim okresie obserwacji ${ }^{55}$.

Równie ciekawą grupę, choć mniej liczną, stanowią kodeksy liturgiczne. Antyfonarz z 1418 r. będący przedmiotem badań głównie specjalistów spuścizny rękopiśmiennej i muzycznej jest cenny nie tylko ze względu na wartość jako dzieła sztuki i iluminatorstwa średniowiecznego, ale i zawarte informacje wykraczające poza sferę sacrum $^{56}$. Fundatorami manuskryptu byli ksieni Katarzyna Zagajewska i pleban parafii strzyżewskiej, prebendy klarysek Mikołaj Goszczyński, skryptorem zaś Stanisław kustosz w tymże w kościele, co zostało zaznaczone na pierwszej karcie rękopisu ${ }^{57}$. Miniatury w postaci dziewięciu inicjałów witrażowych przedstawiają: wjazd Jezusa do Jerozolimy, Zmartwychwstanie, Wniebowstąpienie, Zesłanie Ducha Św., Tron Łaski, Madonnę z Dzieciątkiem, w końcu Św. Klarę dyrygującą chórem zakonnic. Sporządził je malarz związany z środowiskiem artystycznym pracowni Jana z Żytawy ${ }^{58}$. Kodeks zawiera ponadto informacje o architekturze klasztoru, między innymi o dwóch izbach istniejących przed przebudową konwentu w 1418 roku oraz cegielni klasztornej. Za czasów ksieni Zagajewskiej zbudowano kuchnię z kominem oraz łaźnię - obydwa pomieszczenia murowane oraz ozdobiono dwie istniejące już w klasztorze sale ${ }^{59}$.

Kolejny antyfonarz, a w zasadzie jego fragment, gdyż pozostało tylko pięć

${ }^{55}$ Rachunki zakonne cieszyły się do tej pory niewielkim zainteresowaniem badaczy. Zachowała się ich w Polsce, przede wszystkim w archiwach klasztornych bardzo duża liczba, począwszy od XVI w. Wcześniejsze należą do wyjątków. W. Kolak, Rachunki klasztoru augustianów z Krakowa z okresu okupacji szwedzkiej 1655 - 1657, „Krakowski Rocznik Archiwalny”, 8 (2002) s. 105-131; M. Borkowska, Rachunki benedyktynek kowieńskich, „Nasza Przeszłość”, 106 (2006) s. 261-278; A. Szylar, Gospodarowanie benedyktynek sandomierskich, Tarnobrzeg 2008; M. Zdanek, Dochody dominikanów krakowskich $w$ 1. połowie XVI w., w: Inter oeconomiam coelestem et terrenam. Mendykanci a zagadnienia ekonomiczne, red. W. Długokęcki, T. Gałuszka, R. Kubicki, A. Zajchowska, Kraków 2011, s. 259-271; P. Gąsiorowska, Rola ksień klarysek krakowskich w zarządzie majątkiem ziemskim do końca XVIII w., w: Inter oeconomiam coelestem, s. 537-557; O.M. Przybyłowicz, Rachunki klasztorne jako źródło do poznania realiów życia klasztornego. Najstarsza zachowana księga rachunkowa klarysek ze Starego Sacza, w: Realia życia codziennego w Europie Środkowej, red. A. Barciak, Katowice, 2011, s. 197-220.

${ }^{56}$ AAG BK Ms 170 Antyfonarium. I. Pawlak, Graduat klarysek, s. 135-141. A. Moszczyńska, Graduat klarysek; A. Karłowska-Kamzowa, Rola klasztoru w rozwoju gotyckich rękopisów iluminowanych w Polsce, w: Klasztor w kulturze średniowiecznej Polski, red. A. Pobóg-Lenartowicz, M. Derwich, Opole 1995, s. 281-288; B. Miodońska, Średniowieczna książka rękopiśmienna jako dzieło sztuki, Gniezno 1993, s. 102 i n.

${ }^{57}$ AAG BK Ms 170 Antyfonarium, k. 1v: $M^{o} C C C C^{o}$ XVIII in vigilia Concepcionis Sancte Marie iste liber est finitus per Stanislaum ministrum ecclesie in Strzeszewo.

${ }^{58} \mathrm{~W}$. Schenk, Rękopisy liturgiczne od XIII do XV w. w Bibliotece Uniwersyteckiej we Wroctawiu, „ABMK”, 2 (1961) s. 185-207; I. Pawlak, Graduat klarysek, s. 137.

${ }^{59}$ Muraverunt enim predictum monasterium, item eciam construxerunt balneum et coquinam muraverunt et stubas duas antiquas ornaverunt et caminum muraverunt, w: MPH, t. 5, Lwów 1888, Varia et variis codicibus, ed. W. Kętrzyński, s. 957. 
kart pochodzi z XVII w. i zapewne również należał do klarysek gnieźnieńskich ${ }^{60}$. Kodeks „Rozmyślania i różne modlitwy” datowany na przełom XVI i XVII w. zawiera modlitwy, przede wszystkim w języku polskim, w tym jedna zatytułowaną: „Do Anioła stróża swego" ${ }^{61}$. Znajdują się w nim instrukcje o modlitwach, jakie powinna odmawiać zakonnica nad ranem po przebudzeniu, w ciągu dnia i wieczorem oraz koronka smętna do Najświętszej Marii Panny ${ }^{62}$.

Unikatowym zabytkiem jest Modus suscipiendi novitias ad habitum S. Clarae spisany w $1600 \mathrm{r}^{63}$ To najprawdopodobniej najstarszy zachowany na ziemiach polskich rękopis należący do żeńskiej wspólnoty zakonnej zawierający liturgię i opis ceremonii obłóczyn. Zawiera ponadto komentarz i informacje o poszczególnych etapach, a nawet gestach jakie powinny być wykonywane podczas uroczystości tak przez zakonnice, jak i przełożonych ${ }^{64}$. Interesującym jest również fakt, iż na ostatniej karcie zamieszczono skrócony opis postępowania przy przyjmowaniu nowicjuszek w języku polskim: „Pamięć obłóczyn kożdy probantki”.

Ostatni z tej grupy to duży fragment kodeksu Funebrale. Liturgia ceremonii pogrzebu zakonnego spisana została w języku łacińskim, zaś komentarz do poszczególnych części i czynności pożegnania zmarłej klaryski po polsku ${ }^{65}$. Jest

${ }^{60}$ AAG BK Ms 249. Brak informacji proweniencji. Pismo jednej ręki, minuskułą. Tekst rubrykowany z kwadratową notacją muzyczną na 5 liniach, oryginalna paginacja. Zachowane s. 1-4, 21-22, 395-398.

${ }^{61}$ AAG BK Ms 131. Brakuje trzech pierwszych kart i informacji o proweniencji. Bardzo zniszczony, głównie przez insekty, resztki kart naklejone dla wzmocnienia na współczesne karty.

${ }_{62}$ Tamże, k. 13-25: ćwiczenie poranne duchowe, pierwsza myśl nocna albo poranna ma być taka, gdy wstajemy co mamy mówić nabożnego, gdy już wstajesz, gdy się w szaty obłóczysz, po obłóczeniu w szat, pięć rzeczy, które potrzeba zachować w ćwiczeniu porannym, ćwiczenia duchowe przez dzień, k. 37-53 Poczynają się modlitwy o mecze pana naszego Jezusa Chrystusa z rozmyślaniem na wszystkie godziny na jutrznię, na prymę, na tertię, sextę, nonę, nieszpory, kompletę; $\mathrm{k}$. 54-60 ozdoba nabożna czym się ma zabawić z wieczora aż do jutrzni; k. 19v-20r koronka; k. 53v o boleściach NMP.

${ }^{63}$ AAG A. Cap. B 802. O. M. Przybyłowicz, „Pamięć obłóczyn kożdy probantki”, s. 182 i n.

${ }^{64} \mathrm{~W}$ literaturze nadal niewiele informacji o przebiegu obłóczyn. Mało znana jest geneza i etapy kształtowania się obyczaju zaślubin z Niebieskim Oblubieńcem, Jezusem Chrystusem, Borkowska, Życie codzienne, s. 28-30.

${ }^{65}$ AAG BK Ms nr 250 Funebrale zachowane s. 11-62 (oryginalna paginacja). Tekst z notacją muzyczną na pięciu liniach. Pismo jednej ręki minuskułą. Zapewne należący do klarysek z Gniezna, choć brak proweniencji i karty tytułowej. Przybyłowicz, Z badań nad obrzadkiem, s. 201 i n. O pochówkach, a mniej o liturgii K. Sulkowska-Tuszyńska, Klasztor norbertanek w Strzelnie (XII - XVI w.). Sacrum i profanum, Torun 2006; tejże, Rzecz o życiu i śmierci na wzgórzu klasztornym w Strzelnie (XII - XVI w.), w: Premonstratensi na ziemiach polskich $w$ średniowieczu i epoce nowożytnej, ed. J. Rajman 2007, s. 209-221. M. Borkowska, Życie codzienne, rozdz. Lata życia, zgon - i komplikacje po zgonie zajmuje s. 82-89. O ceremoniale pogrzebu opata i opatki w zgromadzeniach mniszych, a więc nie mendykanckich, pisała Elżbieta Dąbrowska czerpiąc jednak informacje głównie z wyników badań archeologicznych prowadzonych na zachodzie Europy, głównie klasztorów męskich, E. Dąbrowska, Ceremoniat pogrzebu opata i opatki w średniowiecznej Europie Lacińskiej, w: E. Dąbrowska, Groby, relikwie i insygnia. Studia z dziejów mentalności średniowiecznej, Warszawa 2008, 73-86; tejże, Liturgia śmierci a archeologia: uwagi o wyborze miejsca pochowania, orientacji, ułożeniu ciała i jego ubiorze w średniowiecznej Europie łacińskiej, w: Groby, relikwie 
to dukt jednej ręki, minuskułą, czerwonym i czarnym atramentem. Brakuje 10 pierwszych kart, zaś liturgia pogrzebu rozpoczyna się od s. 23: ,Jako się sprawować i trzeba przy ciele zmarłej siostry". Przypuszczam, że na brakujących kartach mogły znaleźć się informacje o liturgii sakramentu namaszczenia chorych i modlitwy towarzyszące ostatnim chwilom życia zakonnicy, gdyż podobny układ stosowano zazwyczaj w zakonnych ceremoniałach ${ }^{66}$. To kolejny rękopis, którego dokładna analiza pozwoliła na wniknięcie w obrzędowość oraz realia egzystencji klarysek na ziemiach polskich w epoce nowożytnej. Wszystkie wyżej wymienione źródła umożliwiają pogłębienie wiedzy o duchowości sióstr św. Klary w Gnieźnie oraz przebiegu najistotniejszych ceremonii zakonnych i ich oprawie liturgicznej.

W końcu ostatnia grupa źródeł rękopiśmiennych - kodeksy o charakterze normatywnym. Pierwszy z nich Reguła i konstytucje 1593-1640 zachował się do naszych czasów w bardzo złym stanie, tak iż istniejące fragmenty kart papierowych zostały naklejone na współczesne karty ${ }^{67}$. Drugi - Reguła i Konstytucje 1643 $\mathrm{roku}^{68}$ jest w lepszym stanie. Obydwa zawierają nie tylko prawo zakonne. Wpisy dotyczą realiów życia i zwyczajów konwentu klarysek w Gnieźnie: przebiegu wizytacji zakonnych z pierwszej i drugiej połowy XVII w. ${ }^{69}$, praktyk i obrzędów zakonnych: Porządek dyscypliny, którą mają czynić Siostry i Zakonniczki Świętej Klary, wzięty z Konstytucyi Zakonnych zakonników i braci Świętego Franciszka $^{70}$, Sposób czynienia przysięgi ksieni obranej przed konfirmacyją ${ }^{71}$, Sposób przymowania do zakonu Panien ${ }^{72}$, Sposób professyi czynienia, Ordo velandarum novitiarum (obydwa to skrócone opisy ceremonii w języku łacińskim) ${ }^{73}$, Sposób obierania ksieni wedle kanonów i zwyczajów zakonnych ${ }^{74}$.

Podsumowując prezentację spuścizny rękopiśmiennej klarysek gnieźnieńskich przechowywanej w AAG, wypada stwierdzić, że szczegółowa analiza cennych archiwaliów pozwala poszerzać systematycznie wiedzę nie tylko o Gnieźnie, ale i o funkcjonowaniu klasztorów żeńskich w epoce nowożytnej. Dalsze pra-

i insygnia, s. 95-109. Próba podsumowania stanu wiedzy O. M. Przybyłowicz, Droga do domu Pana. Śmierć i pogrzeb w zakonie klarysek (teoria i praktyka XIII - XVII w.), „KHKM”, 50 (2012) nr 2, s. 227-247.

${ }^{66}$ Rituale Franciscanum [...] ex variis Ritualibus coordinatum a Fr. Bernardo Sannig, Ord. S. Francisci Reform. Provinciae Bohemiae S. Wenceslai D. \& M. Sacerdote \&, Exvicario Generali, edition quarta, Coloniae 1698, Bayerische Staatsbibliothek München, dostęp internetowy 2014.02.27, rozdz. VI De variis ritibus franciscanis et ecclesiasticis, par. XIII Ritus adjuvandi infimum, s. 397-299, par. XIV Ritus benedicendi infirmos, s. 400-407, par. XV Ritus commendationis animae, s. 407-442.

${ }^{67}$ AAG ZKG 1.

${ }^{68}$ AAG ZKG 2, k. 14r-47 r: Haec Constitutiones scriptae \& finita sunt 14 Iulij Anno Domini 1641 także i Reguła.

${ }^{69}$ AAG ZKG 2, k. 51v z 1644 r., 52r i v z 1643, k. 61r z 1627 r., k. 62r z 1645 r., k. 64r z 1633 r., k. 65r z 1655 r., k. 67r z 1637 r., k. 69r z 1640 r.

${ }^{70}$ AAG ZKG 1, k. 2r-4v.

${ }^{71}$ AAG ZKG 2, k. 48v-49v.

${ }^{72}$ Tamże, k. 50v-52v.

${ }^{73}$ Tamże, k. 55r-56v.

${ }^{74}$ Tamże, k. 57r -57v 
ce, szczególnie dokładne rozpoznanie struktury i kodeksów rachunkowych oraz Księgi 1609 źródeł, które nie były do tej pory przedmiotem zainteresowania i badań, dostarczą istotnych, niejednokrotnie nowych obserwacji o funkcjonowaniu tego klauzurowego konwentu w strukturach zakonu, w przestrzeni miasta, w końcu w społeczeństwie nowożytnym. Wielość tematów i zagadnień, które dzięki analizie archiwaliów klarysek w Gnieźnie mogą przyczynić się do pogłębienia stanu obecnej wiedzy dotyczy różnorodnych dziedzin życia: władzy zewnętrznej i wewnętrznej w klasztorze, $\mathrm{w}$ tym hierarchii urzędów, ale także prozopografii (uzupełnienie badań M. Borkowskie), sposobu obierania przełożonych, zarządzania własnością ziemską oraz ekonomii klasztornej, kultury materialnej, standardu życia oraz duchowości.

\section{Źródła archiwalne}

\section{BIBLIOGRAFIA}

Archiwum Archidiecezjalne w Gnieźnie:

Akta Konsystorza, sygn. G VII 2

AKM II 39/4, 39/6

A. Cap. Luzy O 14-52

A. Cap. B 802, 804-819

Dyplomy Gnieźnieńskie nr 867, 886

MS 131, 170, 249, 250

ZKG 1 Reguły i konstytucje 1593-1640

ZKG 2 Reguła zakonu Klary świętej i konstytucje klasztoru gnieźnieńskiego 1603-1759

ZKG 3 Księgi wszystkich spraw konwentu gnieźnieńskiego zakonu S. Klary. To jest katalog wszystkich sióstr zakonnych w tym klasztorze od pamięci ludzkiej professowanych żywych i zmarłych. Przytem inwentarz wszystkich dóbr prowentów także i przywilejów tegoż klasztoru za urzędu Wielebnej w Chrystusie Panny, Panny Doroty Bromierskiej, na ten czas Księniej tegoż klasztoru (acz niegodnej) uczynione, i pilnie pisane w roku pańskim 1609

ZKG 5 Regestr rozchodowy klasztoru gnieźnieńskiego zakonu s. Klary, który po pogorzeniu tegoż klasztoru poczyna się w tym że roku 1613 (do 1655)

ZGK 6 Regestr wziątków i wydatków w konwencie gnieźnieńskim 1701-1730

ZKG 7 Regestr wziątków i wydatków w konwencie gnieźnieńskim 1730-1755

Archiwum Franciszkanów w Krakowie

Karwacki Alojzy, Materiały do historii konwentów franciszkańskich Prowincji Polskiej, t. IX, Essen-Gdańsk 1999

Archiwum Klasztoru Klarysek w Starym Sączu

Księga przywilejów, zapisów rocznych, intercyz Konwentu Starosądeckiego Reguły S. Klary fundaciej Błogosławiony Kunegundy Matki i fundatorki naszej na pamiatkę wieczną z różnych przywilejów pargaminowych i extraktów zapisanych [a]ntycznych wiernie wyjętych dla których lepszy pewności księgę tą przy przyciśnięcia pieczęci klasztorny rękami naszemi podpisałyśmy, działo się Roku Pańskiego 1681 dnia 20 $\mathrm{M}[\mathrm{iesią}] \mathrm{ca}$ Lipca. 
Bayerische Staatsbibliothek München

Rituale Franciscanum [...] ex variis Ritualibus coordinatum a Fr. Bernardo Sannig, Ord. S. Francisci Reform. Provinciae Bohemiae S. Wenceslai D. \& M. Sacerdote \&, Exvicario Generali, edition quarta, Coloniae 1698, http:// Bayerische Staatsbibliothek München (dostęp: 27.02.2014)

\section{Źródła drukowane}

Kronika wielkopolska, w: Monumenta Poloniae Historica, s.n, t. 8, wyd. B. Kürbis, Warszawa 1970.

Memoriale ordinis fratrum a fr. Ioanne de Komorowo compilatum, w: Monumenta Poloniae Historica, t. V, wyd. X. Liske, A. Lorkiewicz, Lwów 1888.

Kodeks dyplomatyczny Wielkopolski, wyd. I. Zakrzewski, t. I, Poznań 1877.

Dochody $i$ wydatki Konwentu Braci Eremitów św. Augustyna przy kościele św. Katarzyny w Kazimierzu. Ze zbiorów Archiwum Państwowego w Krakowie, wyd. Krystyna. Jelonek-Litewka et. al 1: 1502-1505, 2: 1506-1508, Kraków 2002-2004.

\section{Opracowania}

Borkowska Małgorzata, Łatanie pamięci (czyli rzecz o klasztornym kronikarstwie retrospektywnym), ,Znak”, 47 (1995) s. 103-110.

Borkowska Małgorzata, Życie codzienne polskich klasztorów żeńskich w XVII-XVIII w. Warszawa 1996.

Borkowska Małgorzata, Leksykon zakonnic polskich epoki przedrozbiorowej, t. 1: Polska Zachodnia i Pótnocna, Warszawa 2004.

Borkowska Małgorzata, Rachunki benedyktynek kowieńskich, „Nasza Przeszłość”, 106 (2006) s. 261-278.

Burdzy Dominika, „Percepta i expensa”. Budżety obu klasztorów dominikańskich w Sandomierzu w XVII w., w: Klasztor w gospodarce średniowiecznej i nowożytnej, red. M. Derwich, Wrocław 2013, s. 319-332.

Dąbrowska Elżbieta, Ceremoniat pogrzebu opata i opatki w średniowiecznej Europie Łacińskiej, w: E. Dąbrowska, Groby, relikwie i insygnia. Studia z dziejów mentalności średniowiecznej, Warszawa 2008, 73-86.

Dąbrowska Elżbieta, Liturgia śmierci a archeologia: uwagi o wyborze miejsca pochowania, orientacji, ułożeniu ciała $i$ jego ubiorze $w$ średniowiecznej Europie tacińskiej, w: E. Dąbrowska, Groby, relikwie i insygnia. Studia z dziejów mentalności średniowiecznej, Warszawa 2008, s. 95-109.

Gąsiorowska Patrycja, Rola ksień klarysek krakowskich $w$ zarządzie majątkiem ziemskim do końca XVIII w., w: Inter oeconomiam coelestem et terrenam. Mendykanci a zagadnienia ekonomiczne, red. W. Długokęcki i in., ,Studia iŹródła Dominikańskiego Instytutu Historycznego w Krakowie” 9, Kraków 2011, s. 537-557.

Gąsiorowska Patrycja, Obrót gotówka $w$ klasztorze żeńskim na przykładzie osiemnastowiecznych ksiag rachunkowych wybranych klasztorów krakowskich $i$ lwowskich, w: Klasztor $w$ gospodarce średniowiecznej $i$ nowożytnej, red. M. Derwich, Wrocław 2013, s. 303-318.

Jasiński Kazimierz, Przemyst, w: Polski Słownik Biograficzny, t. XXVIII, KrakówWarszawa, 1984-1985, s. 730-733.

Joskowski Zbigniew OFMConv., Stare druki z księgozbiorów klasztornych $w$ zbiorach Biblioteki Prowincjalnej Franciszkanow w Gnieźnie.Apendyks do katalogu starych druków, „Hereditas Monasteriorum”, 5 (2014) s. 303-327. 
Kanior Marian, Polityka antyzakonna władz pruskich i kasata opactw benedyktyńskich $w$ Lubiniu i Mogilnie, w: Kasaty klasztorów na obszarze dawnej rzeczpospolitej Obojga Narodów i na Śląsku na tle procesów sekularyzacyjnych w Europie, t. 2, red. M. Derwich Wrocław 2014, s. 289-298.

Karłowska-KamzowaAlicja, Rola klasztoru wrozwoju gotyckich rękopisówiluminowanych w Polsce, w: Klasztor w kulturze średniowiecznej Polski, red. A. Pobóg-Lenartowicz, M. Derwich, Opole 1995, s. 281-288.

Kłudkiewicz Kamila, Spisy i katalogi wielkopolskich bibliotek klasztornych z klasztorów skasowanych $w$ Wielkopolsce pod rzadami Prus do połowy XIX w. - charakterystyka i znaczenie, „Hereditas Monasteriorum”, 6 (2015) s. 101-142.

Kolak Wacław, Rachunki klasztoru augustianów z Krakowa z okresu okupacji szwedzkiej 1655 - 1657, „Krakowski Rocznik Archiwalny”, 8 (2002) s. 105-131.

Kościelak Sławomir, Sprawozdanie z kwerendy w Geheimes Staatsarchiv Preussicher Kulturbesitz w Berlinie w dniach 4-8 II 2013, „Hereditas Monasteriorum”, 2 (2013), s. 496-497.

Michalski Maciej, Błogosławiona Jolenta - refleksja historyczno-hagiograficznohistoriozoficzna, w: Franciszkanie konwentualni i klaryski w Wielkopolsce od XIII do XIX wieku, red. T. Janiak and D. Stryniak, Gniezno 2006, s. 71-82.

Michalski Maciej, Kobiety i świętość w żywotach księżnych polskich, Poznań 2004.

Miodońska Barbara, Średniowieczna książka rękopiśmienna jako dzieło sztuki, Gniezno 1993.

Mizerka Justyna, Archiwalia poklasztorne, urzędowe, kasacyjne i pokasaycjne w zasobie Archiwum Archidiecezjalnego w Gnieźnie (klasztory powstałe i/lub skasowane przed 1850 r.), „Hereditas Monasteriorum”, 6 (2015) s. 163-236.

Moszczyńska Aleksandra, Graduat klarysek gnieźnieńskich ms.170 z Biblioteki Katedralnej w Gnieźnie, Warszawa 1988, maszynopis w Bibliotece Uniwersytetu Kardynała Stefana Wyszyńskiego w Warszawie.

Ożóg Krzysztof, Przemyst, w: Piastowie. Leksykon biograficzny, red. S. Szczur, K. Ożóg, Kraków 1999, s. 154-161.

Pasiciel Stanisław, Zespół klasztorny franciszkanów i klarysek w Gnieźnie, Gniezno 2005.

Pawlak Ireneusz, Gradual klarysek gnieźnieńskich z 1418 roku jako dokument kultury muzycznej Gniezna, „Nasza Przeszłość”, 24 (1966) s. 135-141.

Przybyłowicz Miriam Olga, Rachunki klasztorne jako źródło do poznania realiów życia klasztornego. Najstarsza ksiegga rachunkowa klarysek ze Starego Sacza, w: Realia życia codziennego w Europie Środkowej ze szczególnym uwzględnieniem Śląska, red. A. Barciak, Katowice - Zabrze 2011, s. 107-130.

Przybyłowicz Miriam Olga, Archiwalia klarysek gnieźnieńskich w Archiwum Archidiecezji Gnieźnieńskiej, cz. 1: Sprawozdanie z kwerendy w dniach 29-31 VIII 2012 r., „Hereditas Monasteriorum”, 1 (2012) s. 456-462.

Przybyłowicz Olga Miriam, Droga do domu Pana. Śmierć i pogrzeb w zakonie klarysek (teoria i praktyka XIII - XVII w.), „Kwartalnik Historii Kultury Materialnej”, 60 (2012) $\mathrm{nr}$ 2, s. 227-247.

Przybyłowicz Miriam Olga, Archiwalia klarysek gnieźnieńskich w Archiwum Archidiecezji Gnieźnieńskiej, cz. 2: Sprawozdanie z kwerendy w dniach 9-12 VII 2013 r., „Hereditas Monasteriorum", 3 (2013) s. 552-569.

Przybyłowicz Olga Miriam, Jak panny zakonne rozliczały się? Księgi rachunkowe jako źródto do badań nad polskimi klasztorami żeńskimi w XVI-XVIII w., w: Klasztor $w$ gospodarce średniowiecznej $i$ nowożytnej, red. M. Derwich, Wrocław 2013, s. 101-114. 
Przybyłowicz Miriam Olga, „Pamięć obłóczyn kożdy probantki”. Ceremonia obłóczyn $w$ świetle rękopisu Modus suscipiendi novitias ad habitum S. Clarae z $1600 \mathrm{r}$. z klasztoru klarysek gnieźnieńskich, „Hereditas Monasteriorum”, 3 (2013) s. 179-194.

Przybyłowicz Miriam Olga, Zajac, dwa złote na pieprz i kary za gry hazardowe. Dwa przywileje klarysek dla miasta Kostrzyna z 1477 i 1615 r., w: Ecclesia Regnum Fontes. Studia z dziejów średniowiecza. Prace ofiarowane Profesor Marii Koczerskiej. Warszawa 2014, s. 138-149.

Przybyłowicz Olga Miriam, Z badań nad obrzadkiem pogrzebowym klarysek - liturgia i miejsca pochówku w klasztorach na ziemiach polskich, w: Epigraphica et Sepulcralia, t. 6, ed. J. Roháček, Praha 2015, s. 201-224.

Przybyłowicz Miriam Olga, Reguła zakonna jest wozem do nieba. Realia życia w klasztorach klarysek w Matopolsce, Wielkopolsce i na Ślasku, Warszawa 2016.

Przybyłowicz Miriam Olga, Rękopis Księgi wszystkich spraw Konwentu Gnieźnieńskiego zakonu S. Klary [...] pilnie pisane w roku pańskim 1609 i jego zawartość, „Hereditas Monasteriorum", 7 (2016) s. 247-263.

Przybyłowicz Olga Miriam, Źródła do poznania gospodarki w dobrach wiejskich klarysek gnieźnieńskich od końca XVI do schytku XVII stulecia, „Kwartalnik Historii Kultury Materialnej", 65 (2017) nr 4, s. 447-460.

Przybyłowicz Olga Miriam, Lista ksień konwentu gnieźnieńskiego XVI-XIX w., złożone do druku.

Przybyłowicz Olga Miriam, Dyplomy i akta klasztoru klarysek w Gnieźnie. Charakterystyka zbioru i sposoby uwierzytelniania $w$ praktyce konwentu zakonnic św. Klary, oddane do druku.

Przybyłowicz Olga Miriam, Documents of Polish kings issued for the monastery of the Poor Clares in Gniezno (16th-18th centuries). Kings as the protectors of the convent, w: Orden und Stadt, Orden und ihre Wohlthäter. Monastica historia 4, red. J.M. Havlík, J. Hlaváčková, K. Kollermann, Prag -St. Pölten 2019, s. 463-483.

Rył Jadwiga, Katalog rękopisów biblioteki katedralnej w Gnieźnie, Lublin 1982.

Schenk Wacław, Rękopisy liturgiczne od XIII do XV w. w Bibliotece Uniwersyteckiej we Wrocławiu, „Archiwa Biblioteki Muzea Kościelne”, 2 (1961) s. 185-207.

Sulkowska-Tuszyńska Krystyna, Klasztor norbertanek $w$ Strzelnie (XII-XVI w.). Sacrum i profanum, Toruń 2006.

Sulkowska-Tuszyńska Krystyna, Rzecz o życiu $i$ śmierci na wzgórzu klasztornym $w$ Strzelnie (XII - XVI w.), w: Premonstratensi na ziemiach polskich $w$ średniowieczu i epoce nowożytnej, red. J. Rajman 2007, s. 209-221.

Szylar Anna, Gospodarowanie benedyktynek sandomierskich, Tarnobrzeg 2008.

Szylar Anna, Kronika bernardynek lubelskich 1618-1885, Źródła i Monografie KUL, 353. Prace z Historii Szkolnictwa i Opieki Społecznej w Polsce 3, Lublin 2009.

Szylar Anna, ,Sprawa o tym jak benedyktynki gospodarstwo prowadzity”. Organizacja i funkcjonowanie gospodarki opactwa benedyktynek w Sandomierzu w XVII i XVII w., w: Klasztor w gospodarce średniowiecznej i nowożytnej, red. M. Derwich, Wrocław 2013, s. 447-460.

Szulc Alicja, Klasztory franciszkańskie w średniowiecznej Wielkopolsce, Poznań 2001.

Targosz Karolina, Piórem zakonnicy. Kronikarki w Polsce XVII w. o swoich zakonach i swoich czasach, Kraków 2002.

Zdanek Maciej, Dochody dominikanów krakowskich w 1.pot. XVIw., w: Inter oeconomiam coelestem et terrenam. Mendykanci a zagadnienia ekonomiczne, red. W. Długokęcki et. al., Studia i Źródła Dominikańskiego Instytutu Historycznego w Krakowie 9, Kraków 2011, s. 259-271. 


\section{MANUSCRIPT SOURCES FROM THE POOR CLARES CONVENT IN GNIEZNO HELD IN THE ARCHDIOCESAN ARCHIVE IN GNIEZNO: OUR KNOWLEDGE, LEGACY AND RESEARCH OPPORTUNITIES}

\section{Summary}

The aim of the article is to present and analyse the manuscript legacy of the Poor Clares Convent in Gniezno. After the dissolution of the convent in the nineteenth century (likely the second half), this legacy was transferred to the Archive of the Metropolitan Chapter, and is currently held in the Archdiocesan Archive in Gniezno. So far, researchers have not been particularly interested in studying this material. This collection consists of manuscripts, documents and parchment diplomas, most of which are in the form of loose records (A. Cap) over 2,500 items and over 4,000 cards.

27 manuscripts are held in a few collections: six items in the fonds of the Poor Clares Convent (ZKG) and 21 in the division of the Archive of the Metropolitan Chapter (A. Cap. B). The latter relate to economic and accounting matters. The manuscripts fall into three categories: a legal and normative category which comprises monastic rules and constitutions (two documents), a category which includes liturgical books (five) and the records on the ceremony of taking the veil, and the most numerous group - material relating to economic and accounting matters. The third category contains 10 manuscripts of expenses and/or income of the convent (even the oldest one from 1613), the inventory of the Poor Clares' rural property of 1593, and 10 items dating back to the second half of the eighteenth century containing settlements with the convent's serfs in the town of Kostrzyn and villages which belonged to this monastic congregation. A precious document that fits into the monastic literary output of the early modern period is the code entitled "The books of all matters of the Gniezno Convent of the Poor Clares. This is a catalogue of all the nuns who ever took monastic vows in this convent, both dead and alive. This is also the inventory of the whole property of the convent, its farm income and privileges [...] diligently written in 1609 AD". The code consists of 802 paper pages with several dozen types of handwriting. The data it contains are prosopographic and economic (over half of them) details, information about the realities of life and the functioning of this enclosed community.

Despite being a small collection, the manuscripts are an extremely valuable legacy due to the wide range of information they contain. Loose records have an even greater amount of information. A comprehensive and detailed study of the material mentioned above, particularly the economic and accounting manuscripts, will shed light on the methods of managing the convent estate, the finances of the congregation in the sixteenth-eighteenth centuries, and the functioning of the convent in the urban economy and society of Gniezno in the early modern period. Only a detailed analysis will make it possible to answer a number of questions about the internal affairs of the convent, its material culture, the everyday life of the nuns, and above all the convent estate: the profitability of the property, a budget, the structure of income statement accounts and the standard of living of the nuns.

Key words: monasticism; the Poor Clares; Gniezno; archival material; manuscripts 